\title{
Analisis Minat Belajar Siswa dan Implikasinya Terhadap Layanan Bimbingan dan Konseling
}

\author{
Afiatin Nisa ${ }^{1}$, Dian Renata ${ }^{1}$ \\ ${ }^{1}$ Universitas Indraprasta PGRI \\ afiatinnisa83918@gmail.com; renadhi83@gmail.com
}

Submitted: 05-10-2018, Revised: 24-11-2018, Accepted: 24-12-2018

\begin{abstract}
The aim of this study is to find out students learning interest and its implication toward counseling and guidance service. Research method used is descriptive qualitative. The data taken by questionnaire, observation and interview. There are 30 question on the questionnaire given to 45 students. The questionnare is given to the respondents of counseling and guidance teacher, headmaster, and students. Observation is done by observing the learning process. Data analysis technique is done by collecting, grouping, analyzing, and interpreting the data. The result shows that the analysis of students learning interest and its implication toward counseling and guidance service is in Good Category.
\end{abstract}

Keywords: Students Learning Interest; Counselling and Guidance Servic

\begin{abstract}
Abstrak: Tujuan Penelitian adalah untuk mengetahui minat belajar siswa dan implikasinya terhadap layanan bimbingan dan konseling. Metode penelitian yang digunakan adalah kualitatif deskriptif. Dengan pengumpulan data menggunakan angket, observasi dan wawancara. Angket yang digunakan sebanyak 30 butir pernyataan dengan sumber data 45 siswa. Angket ditujukan dengan siswa sebagai responden, wawancara dilakukan terhadap Guru Bimbingan dan Konseling, Kepala Sekolah dan Guru Mata Pelajaran dan observasi dilakukan dengan mengamati proses belajar siswa dan lingkungan serta keberadaan sekolah. Teknik analisis data dilakukan dengan cara mengumpulkan, mengelompokkan, menganalisis data, dan menginterpretasikan data. Hasilnya adalah Analisis Minat Belajar Siswa dan Implikasinya Terhadap Layanan Bimbingan dan Konseling di SMP YASPEN Tugu Ibu 2 Depok, dalam kategori Baik.
\end{abstract}

Kata Kunci: Minat Belajar Siswa; Layanan Bimbingan dan Konseling

\section{Pendahuluan}

Sekolah adalah tempat dimana pendidikan formal berlangsung yang di dalamnya terdapat aturan-aturan yang harus di taati dan dijalankan oleh semua anggota masyarakat sekolah yang ada di dalam lingkungan sekolah tersebut. Kaitanya dengan bimbingan dan konseling di sekolah, terlebih dahulu kita harus mengetahui apa itu bimbingan konseling. Bimbingan konseling itu sendiri adalah suatu batuan yang diberikan oleh konselor (orang yang ahli) kepada konseli (siswa) agar konseli mampu menyelesaikan masalah yang dihadapi dan juga mampu mengembangkan potensi yang dimiliki baik dari aspek pribadi sosial, aspek akademik (belajar) dan aspek karir. Bimbingan dan konseling di sekolah memfasilitasi pengembangan siswa baik secara individual atau pun kelompok. Bimbingan dan konseling juga bisa diberikan secara klasikal sesuai dengan kebutuhan, potensi bakat dan minat yang dimiliki oleh siswa. Bimbingan merupakan bantuan yang diberikan kepada klien (siswa) agar potensi yang dimiliki berkembang secara optimal dengan jalan memahami diri, memahami lingkungan, mengatasi hambatan guna menentukan rencana masa depan yang baik. Konseling merupakan suatu bentuk bantuan yang diberikan oleh konselor kepada klien (siswa) dengan melalui serangkaian wawancara guna membantu menyelesaikan masalah yang dialami oleh klien, sehingga klien mampu menyelesaikan masalah yang dialami secara mandiri. Bagi Guru Bimbingan dan Konseling Mempelajari literatur/bacaan yang relevan dengan bimbingan dan konseling komprehensif agar 
paham bimbingan dan konseling komprehensif yang diharapkan dapat memperlancar pelaksanaan program layanan bimbingan dan konseling komprehensif(Kurniawan, 2015).

Keberadaan bimbingan dan konseling saat ini sangat dibutuhkan di sekolah untuk membantu para siswa dalam menyelesaikan masalah-masalah yang dialami oleh siswa. Dengan berbagai layanan-layanan bimbingan dan konseling yang terdiri dari layanan orientasi, layanan informasi, layanan penempatan dan penyaluran, layanan penguasaan konten, layanan konseling peroranagan, layanan bimbingan kelompok, layanan konseling kelompok, layanan konsultasi, layanan mediasi dan layanan advokasi yang memungkinkan peserta didik untuk mengembangkan diri yang berkenaan minat belajar(Permana, 2015). Sehingga siswa memiliki ketertarikan dalam proses belajar dan memiliki pencapaian hasil belajar yang tinggi sesuai dengan kemampuan dan memiliki minat belajar yang semakin meningkat serta mengatasi terjadinya kebiasaan-kebiasaan yang tidak baik, yang dilakukan oleh siswa dalam proses belajar mengajar berlangsung. Sekolah merupakan lembaga formal dimana seseorang individu mendapatkan pendidikan serta pengajaran untuk dapat berhubungan dengan orang lain dan lingkungan. Minat yang dimiliki oleh siswa dapat memunculkan karakter dan kepribadian individu itu sendiri, misalnya kemandirian dalam belajar yang sangat berpengaruh pada proses belajar serta prestasi yang akan diperoleh. Serta individu mampu merencanakan, melaksanakan dan mengevaluasi cara belajar sesuai dengan potensi dan minat yang dimiliki. Berbagai layanan bimbingan dan konseling diberikan pada siswa, terutama layanan yang cocok untuk masalah belajar siswa dalam meningkatkan minat belajar siswa(Abidin, 2006). Karena di dalam proses belajar di sekolah ditemui banyak karakter siswa yang beranekaragam. Ada siswa yang mampu dan berhasil mengikuti kegiatan belajar secara lancar tanpa mengalami kesulitan, tetapi ada juga siswa yang mengalami berbagai kesulitan dalam mengikuti kegiatan belajar. Kesulitan tersebut terlihat dengan masih banyaknya siswa di sekolah yang mengalami kesulitan dalam belajar yang diakibatkan oleh siswa merasa jenuh, kurang memiliki ketertarikan untuk belajar, bosan dengan pelajaran yang diperoleh, malas untuk berpikir dan malas untuk mengerjakan tugas yang diberikan oleh guru mata pelajaran. Hal ini terjadi karena kurangnya kemandirian dan minat belajar yang dimiliki oleh siswa. Selain itu ada juga hambatan-hambatan yang mempengaruhi pencapaian hasil belajar yang kurang optimal seperti halnya kesadaran diri dan kepercayaan diri yang kurang dimiliki oleh siswa, sehingga menimbulkan perilaku-perilaku siswa menjadi malas belajar dan sering mengandalkan teman-temannya dalam mengerjakan tugas dari guru mata pelajaran. Oleh karena itu perlu adanya tidakan yang harus dilakukan oleh guru bimbingan dan konseling untuk membantu siswa dalam mengatasi kesukaran-kesukaran yang di alami oleh siswa dalam hal kaitannya dengan proses pembelajaran di sekolah.

Minat yang dimiliki seseorang dapat muncul dengan sendirinya, orang tua atau lingkungan hanya dapat memberi stimulas agar minat seseorang dapat tumbuh berkembang. Minat sangat bersifat pribadi dan minat berbeda antara satu orang dengan lainnya. Dalam diri seseorang berbeda-beda dari waktu ke waktu. Menurut Arif Zainudin (2012:19), mengemukakan bahwa "minat dirumuskan dalam Encyclopedia of Psychology adalah faktor yang ada dalam diri seseorang, yang menyebabkan ia tertarik atau menolak terhadap objek, orang dan kegiatan dalam lingkungannya".

Menurut Slameto minat adalah satu rasa yang lebih suka dan rasa ketertarikan pada suatu hal atau aktivitas tanpa ada yang menyuruh(Slameto, 2010). Menurut Crow dan Crow dalam Nurkancana (2007:25), minat adalah "sebagai kekuatan dorongan yang menyebabkan individu memberikan perhatian kepada seseorang sesuatu atau aktifitas tertentu". Menurut Ahmadi (2009:148) berpendapat bahwa, "minat adalah sikap jiwa seorang termasuk ketiga fungsi jiwanya 
(kognisi, konasi, dan emosi), yang tertuju pada sesuatu, dan dalam hubungan itu unsur perasaan yang terkuat". Menurut Syah (2001:136) berpendapat bahwa, "minat adalah kecenderungan dan kegairahan yang tinggi atau keinginan yang besar terhadap sesuatu".

Dari beberapa pengertian di atas maka dapat dipahami bahwa minat merupakan perasaan senang dan tertarik pada suatu kegiatan atau obyek, dan kesenangan itu cenderung untuk memperhatikan dan akhirnya aktif berkecimpung dalam kegiatan tersebut. Seseorang yang memiliki minat terhadap suatu aktifitas maka akan memperhatikan secara konsisten dengan perasaan yang senang. Ada beberapa macam teori belajar yang dikenal dan dijadikan acuan oleh para guru atau pendidik dalam proses belajar mengajar. Menurut Skinner dalam Dimyati berpendapat bahwa "belajar adalah suatu perilaku". Pada saat orang belajar, maka responsnya menjadi lebih baik(Dimyati \& Mudjiono, 2009). Sebaliknya, bila ia tidak belajar maka responsnya menurun. Dalam belajar ditemui adanya hal sebagai berikut :

a) Kesempatan terjadinya peristiwa yang menimbulkan respon pembelajar.

b) Respons si pembelajar.

c) Konsekuensi yang bersifat menguatkan respons tersebut. Pemerkuat terjadi pada stimulus yang menguatkan kensekuensi tersebut. Sebagai ilustrasi, perilaku respons si pebelajar yang baik, diberi hadiah. Sebaliknya, perilaku respons yang tidak baik diberi teguran dan hukuman.

Menurut Romine berpendapat bahwa "belajar merupakan suatu proses, dan bukan hasil yang hendak dicapai semata(Hamalik, 2007). Proses itu sendiri berlangsung melalui serangkaian pengalaman, sehingga terjadi modifikasi pada tingkah laku yang telah dimiliki sebelumnya". Menurut Gronbach dalam Suryabrata di bukunya Educational Psychology yang menyatakan bahwa "learning is shown by a chang in behavior as a result of experience, belajar yang sebaikbaiknya adalah dengan mengalami, dan dalam mengalami itu si pelajar menggunakan panca indranya"(Suryabrata, 2011). Belajar adalah perubahan yang terjadi melalui latihan dan pengalaman". Menurut Slameto belajar adalah suatu proses usaha yang dilakukan sesorang untuk memperoleh suatu perubahan tingkah laku yang baru secar keseluruhan, sehingga hasil pengalamannya sendiri dalam interaksi dengan lingkungannya. Pendapat di atas dapat memperlihatkan bahwa belajar merupakan suatu proses atau aktifitas seseorang untuk memperoleh perubahan tingkah laku, pengetahuan, meningkatkan keterampilan sehingga menjadi lebih baik dari sebelumnya(Slameto, 2003).

Berdasarkan pengertian-pengertian di atas maka minat belajar adalah kecenderungan dan perhatian dalam belajar. Minat belajar adalah aspek psikologi seseorang yang menampakkan diri dalam beberapa gejala, seperti gairah, kemauan, perasaan suka untuk melakukan proses perubahan tingkah laku melalui berbagai kegiatan yang meliputi mencari pengetahuan dan pengalaman, minat belajar itu mempunyai ketergantungan pada faktor internal seseorang (siswa) seperti perhatian, kemauan dan kebutuhan terhadap belajar yang ditunjukkan melalui keantusiasan, partisipasi dan keaktifan dalam belajar. Dalam kegiatan belajar, siswa membutuhkan minat untuk mengikuti proses belajar dengan baik, dalam hal ini ada dua faktor yang mempengaruhu minat belajar siswa yaitu faktor intern dan ekstern. Dalam meningkatkan minat belajar siswa tentunya membutuhkan adanya upaya layanan bimbingan dan konseling terhadap minta belajar siswa.

Menurut Prayitno adapun layanan bimbingan dan konseling sebagai berikut(Prayitno, 2013) :

a.) Layanan Orientasi 
Layanan orientasi berupaya menjembatani kesenjangan antara seseorang dengan suasana ataupun objek-objek baru. Layanan ini juga secara langsung ataupun tidak langsung "mengantarkan" orang yang dimaksut suasana ataupun objek baru agar ia dapat mengambil manfaat berkenaan dengan situasi atau objek baru itu.

Tujuan layanan orientasi ini terdiri dari dua tujuan yaitu sebagai berikut :

1) Tujuan umum, layanan orientasi berupaya mengantarkan individu untuk memasuki suasana atau lingkungan baru. Melalui layanan ini individu mempraktekakan berbagai kesempatan untuk memahami dan mampu melakukan kontak secara konstruktif dengan bebagai elemen suasana baru tersebut.

2) Tujuan khusus, layanan orientasi ini berkaitan dengan fungsi pemahaman. Individu memahami berbagai hal yang penting dari suasana yang baru dijumpainya, kemudian mengolah hal-hal baru tersebut sehingga dapat digunakan untuk sesuatu yang menguntungkan.

b.) Layanan informasi

Layanan informasi berusaha memenuhi kekurangan akan informasi yang mereka perlukan.

Dalam layanan ini, kepada peserta layanan disampaikan berbagai informasi, infomasi kemudian diolah dan digunakan oleh individu untuk kepentingan hidup dan perkembangan. layanan informasi ini diselenggarakan oleh konselor dan diikuti oleh seseorang atau lebih.

Adapun tujuan dari pemberian layanan informasi yaitu sebagai berikut: Tujuan umum, tujuan umum layanan informasi adalah dikuasainya informasi tertentu oleh peserta layanan informasi tersebut selanjutnya digunakan oleh peserta untuk keperluan hidup sehari-hari terkait dengan perkembangan dirinya.

Tujuan khusus, tujuan khusus layanan informasi terkait dengan fungsi-fungsi konseling. Fungsi pemahaman, paling dominana dan paling langsung diemban oleh layanan informasi. Peserta layanan memahami informasi dengan berbagai seluk-beluk sebagai isi layanan. Penguasaan informasi tertentu dapat digunakan untuk pemecahan masalah serta untuk mencegah timbulnya masalah, untuk mengembangkan dan memelihara potensi yang ada dan untuk memungkinkan peserta bersangkutan membuka diri dari dalam mengaktualisasukan hak-haknya. Dalam hal pengembangan kemandirian, pemahaman dan penguasaan terhadap informasi yang diperlukan akan mungkin ia mampu memahami dan menerima diri dan lingkunganya secara objektif, positif dan dinamis, mengambil keputusan, mengarahkan diri untuk kegiatan-kegiatan yang berguna sesuai dengan keputusan yang diambil dan akhirnya mengaktualisasikan diri. Berdasarkan yang dikemukakan di atas, maka tujuan penelitian ini adalah untuk menganalisis Minat Belajar Siswa dan Implikasinya terhadap Bimbingan Konseling

\section{Metode Penelitian}

Dalam pendekatan penelitian ini penulis menggunakan metode penelitian kualitatif jenis deskriptif. Dengan menggunakan metode tersebut diharapkan penulis mendapatkan gambaran nyata sesuai dengan fakta yang ada pada saat penelitian dilakukan. Penelitian deskriptif merupakan penelitian yang dimaksut untuk menyelidiki keadaan, kondisi atau hal lain-lain yang sudah disebutkan, yang hasilnya dipaparkan dalam bentuk laporan penelitian(Arikunto, 2010).

Melalui pendekatan deskriptif penulis mengumpulkan data dan informasi selengkaplengkapnya mengenai minat belajar siswa dan implikasi terhadap layanan bimbingan dan konseling di SMP YASPEN Tugu Ibu 2 Depok. Penelitian ini yang menjadi sumber data penelitian adalah siswa kelas VIII di SMP YASPEN Tugu Ibu 2 Depok yang jumlahnya 45 siswa, guru bimbingan dan konseling, guru mata pelajaran dan kepala sekolah. Siswa kelas VIII 
yang berjumlah 45 ini terdiri dari kelas VIII-1 dan kelas VIII-2. Dalam menetapkan sampel sumber data, penulis menggunakan teknik purposive sampling. Menurut Sugiono (2015:218) purposive sampling yaitu "menentukan sampel dengan pertimbangan tertentu yang dipandang dapat memberikan data secara maksimal". Dalam penelitian ini diadakan tanya jawab dengan , guru mata pelajaran, guru bimbingan dan konseling mengenai bagaimana meningkatkan minat belajar siswa di SMP YASPEN Tugu Ibu 2 Depok. Setelah seluruh data yang terkumpul melalui instrumen penelitian, yang penulis lakukan adalah menganalisis data tersebut untuk memperoleh gambaran tentang Analisis Minat Belajar Siswa dan Implikasinya Terhadap Layanan Bimbingan dan Konseling di SMP YASPEN Tugu Ibu 2 Depok.

\section{Hasil dan Pembahasan}

Data yang telah terkumpul melalui instrument penelitian (angket) dikelompokkan sesuai dengan jawaban yang sama yaitu: ya, kadang-kadang, tidak pernah ke dalam tabulasi pengelompokkan data (Tabel I) dan kemudian data tersebut satu-satunya dipresentasikan ke dalam tabulasi presentase data (Tabel II). Penjabarannya adalah sebagai berikut:

Tabel I Tabulasi Pengelompokan Data $n=45$

\begin{tabular}{|c|c|c|c|c|}
\hline \multirow[b]{2}{*}{ No } & \multirow{2}{*}{ Pernyataan } & \multicolumn{3}{|c|}{ Frekuensi Jawaban } \\
\hline & & YA & KD & $\mathbf{T P}$ \\
\hline 1 & Saya aktif mengikuti pembelajaran sesuai dengan jadwal yang ada. & 33 & 12 & 0 \\
\hline 2 & $\begin{array}{l}\text { Saya menyimak pelajaran dengan baik saat pembelajaran sedang } \\
\text { berlangsung. }\end{array}$ & 22 & 12 & 0 \\
\hline 3 & $\begin{array}{l}\text { Saya bertanya ketika saya tidak mengerti tentang materi yang } \\
\text { sedang dijelaskan oleh guru. }\end{array}$ & 12 & 30 & 3 \\
\hline 4 & $\begin{array}{l}\text { Saya mendapat dorongan dari orang tua agar serius dalam } \\
\text { mengikuti pembelajaran di sekolah. }\end{array}$ & 45 & 10 & 0 \\
\hline 5 & Perhatian saya sangat besar untuk belajar & 18 & 27 & 0 \\
\hline 6 & $\begin{array}{l}\text { Rajin belajar sangat bermanfaat bagi kehidupan, oleh karena itu } \\
\text { belajar sangat menarik minat saya }\end{array}$ & 14 & 30 & 1 \\
\hline 7 & $\begin{array}{l}\text { Saya berusaha mendapatkan nilai yang baik dalam semua mata } \\
\text { pelajaran }\end{array}$ & 39 & 6 & 0 \\
\hline 8 & $\begin{array}{l}\text { Saya mengerjakan sendiri tugas-tugas yang diberikan oleh guru } \\
\text { mata pelajaran }\end{array}$ & 30 & 15 & 0 \\
\hline 9 & Saya selalu mengumpulkan tugas tepat waktu & 13 & 32 & 0 \\
\hline 10 & $\begin{array}{l}\text { Saya selalu memanfaatkan kesempatan yang diberikan guru untuk } \\
\text { mengungkapkan pendapat }\end{array}$ & 8 & 30 & 7 \\
\hline 11 & $\begin{array}{l}\text { Ketika mengikuti proses belajar di kelas saya merasa sangat } \\
\text { bersemangat }\end{array}$ & 13 & 29 & 3 \\
\hline 12 & Saya mendapat wawasan baru yang bermanfaat setelah belajar & 29 & 15 & 1 \\
\hline 13 & Saya peduli dengan nilai yang saya peroleh & 40 & 5 & 0 \\
\hline 14 & $\begin{array}{l}\text { Saya mendapatkan dorongan dari orang tua saya untuk lebih rajin } \\
\text { belajar }\end{array}$ & 38 & 7 & 0 \\
\hline 15 & Saya bersemangat untuk belajar karena teman saya membei & 14 & 28 & 3 \\
\hline
\end{tabular}


motivasi untuk belajar

16 Guru bimbingan konseling memberikan layanan secara klasikal $29 \quad 16 \quad 0$ kepada siswa

17 Guru bimbingan dan konseling memberikan layanan bimbingan $\begin{array}{llll}18 & 26 & 1\end{array}$ secara kelompok kepada siswa

18 Guru bimbingan dan konseling memberikan layanan konseling $24 \quad 19 \quad 2$ secara individual kepada siswa

19 Guru bimbingan dan konseling memberikan jadwal khusus dalam $\begin{array}{llll}19 & 24 & 2\end{array}$ memberikan layanan yang berkaitan dengan bidang belajar kepada siswa

20 Guru bimbingan dan konseling memberikan layanan informasi 31 tentang minat belajar kepada siswa

21 Guru bimbingan dan konseling memberikan arahan tentang cara 34 menumbuhkan minat belajar pada siswa 22 Guru bimbingan dan konseling menjelaskan tentang kegunaan 26

23 Guru bimbingan dan konseling bantuan tentang penyesuaian diri 36 siswa dengan lingkungan sekolah

24 Guru bimbingan dan konseling memfasilitasi siswa dalam $22 \quad 22 \quad 1$ berkonsultasi tentang minat belajar

25 Keberadaan layanan bimbingan dan konseling yang diberikan oleh guru bimbingan dan konseling sangat bermanfaat bagi siswa dalam menumbuhkan minat belajar

26 Dengan adanya perpustakaan disekolah siswa menjadi lebih $14 \quad 25 \quad 6$ berminat untuk belajar

27 Dengan adanya laboratorium komputer siswa bisa mendapatkan 38 pengetahuan baru dalam belajar

28 Lingkungan sekolah yang bersih membuat saya merasa nyaman $\begin{array}{llll}39 & 5 & 1\end{array}$ untuk belajar

29 Guru bimbingan dan konseling memberikan layanan mediasi $\begin{array}{llll}30 & 15 & 0\end{array}$ ketika ada siswa yang sedang berselisih dengan teman ataupun guru

30 Guru bimbingan dan konseling memberikan layanan advokasi ketika siswa tidak mendapatkan proses pembelajaran seperti yang seharusnya.

Berdasarkan hasil tabel I, selanjutnya penulis mempresentasekan data yang telah dikelompokkan sesama jenisnya ke data tabulasi presentase data (Tabel II) : 
Tabel 2. Tabulasi Persentase Data $n=45$

No PERNYATAAN FREKUENSI PERSENTASE (\%)

1. Saya aktif mengikuti pembelajaran sesuai
dengan jadwal yang ada

4. Saya mendapat dorongan dari orang tua agar serius dalam mengikuti pembelajaran di sekolah.

5. Perhatian saya sangat besar untuk belajar

6. Rajin belajar sangat bermanfaat bagi

$\begin{array}{llllll}18 & 27 & 0 & 40 & 60 & 0\end{array}$

kehidupan, oleh karena itu belajar sangat

$\begin{array}{llllll}14 & 30 & 1 & 31 & 67 & 2\end{array}$
menarik minat saya

7. Saya berusaha mendapatkan nilai yang baik dalam semua mata pelajaran

8. Saya mengerjakan sendiri tugas-tugas yang diberikan oleh guru mata pelajaran

9. Saya selalu mengumpulkan tugas tepat waktu

10. Saya selalu memanfaatkan kesempatan yang diberikan guru untuk mengungkapkan pendapat

11. Ketika mengikuti proses belajar di kelas saya merasa sangat bersemangat

12. Saya mendapat wawasan baru yang bermanfaat setelah belajar

13. Saya peduli dengan nilai yang saya peroleh

14. Saya mendapatkan dorongan dari orang tua saya untuk lebih rajin belajar

.15. Saya bersemangat untuk belajar karena teman saya membei motivasi untuk belajar

16. Guru bimbingan konseling memberikan layanan secara klasikal kepada siswa

$\begin{array}{cccccc}39 & 6 & 0 & 87 & 13 & 0 \\ 30 & 15 & 0 & 67 & 33 & 0 \\ 13 & 32 & 0 & 29 & 71 & 0 \\ 8 & 30 & 7 & 18 & 67 & 15\end{array}$

$\begin{array}{llllll}13 & 29 & 3 & 29 & 64 & 7\end{array}$

$\begin{array}{llllll}29 & 15 & 1 & 65 & 33 & 2\end{array}$

$\begin{array}{llllll}40 & 5 & 0 & 89 & 11 & 0\end{array}$

$\begin{array}{llllll}38 & 7 & 0 & 84 & 16 & 0\end{array}$

$\begin{array}{llllll}14 & 28 & 3 & 31 & 62 & 7\end{array}$

$\begin{array}{llllll}29 & 16 & 0 & 64 & 36 & 0\end{array}$ 
17. Guru bimbingan dan konseling memberikan layanan bimbingan secara kelompok kepada siswa

18. Guru bimbingan dan konseling memberikan layanan konseling secara individual kepada siswa

19. Guru bimbingan dan konseling memberikan jabwal khusus dalam memberikan layanan yang berkaitan dengan bidang belajar kepada siswa

20. Guru bimbingan dan konseling memberikan layanan informasi tentang minat belajar kepada siswa

21. Guru bimbingan dan konseling memberika arahan tentang cara menumbuhkan .minat belajar pada siswa

22. Guru bimbingan dan konseling memberika arahan tentang cara menumbuhkan .minat belajar pada siswa

23. Guru bimbingan dan konseling bantuan tentang penyesuaian diri siswa dengan lingkungan sekolah

24. Guru bimbingan dan konseling memfasilitasi siswa dalam berkonsultasi tentang minat belajar

25. Keberadaan layanan bimbingan dan konseling $\quad \begin{array}{lllllll}32 & 13 & 0 & 71 & 29 & 0\end{array}$ yang diberikan oleh guru bimbingan dan konseling sangat bermanfaat bagi siswa dalam menumbuhkan minat

26. Dengan adanya perpustakaan disekolah siswa menjadi lebih berminat untuk belajar

$\begin{array}{llllll}19 & 24 & 2 & 42 & 53 & 5\end{array}$

$\begin{array}{llllll}31 & 13 & 1 & 69 & 29 & 2\end{array}$

$\begin{array}{llllll}34 & 11 & 0 & 67 & 24 & 0\end{array}$

$\begin{array}{llllll}26 & 19 & 0 & 58 & 42 & 0\end{array}$

$\begin{array}{llllll}36 & 9 & 0 & 80 & 20 & 0\end{array}$

$\begin{array}{llllll}22 & 22 & 1 & 49 & 49 & 2\end{array}$

27. Dengan adanya laboraturium komputer siswa $\quad \begin{array}{lllllll}38 & 7 & 0 & 84 & 16 & 0\end{array}$ bisa mendapatkan pengetahuan baru dalam belajar

28. Lingkungan sekolah yang bersih membuat saya merasa nyaman untuk belajar 


\begin{tabular}{lllllll}
\hline 29. $\begin{array}{l}\text { Guru bimbingan dan konseling memberikan } \\
\text { layanan mediasi ketika ada siswa yang sedang } \\
\text { berselisis dengan teman ataupun guru }\end{array}$ \\
30. $\begin{array}{l}\text { Guru bimbingan dan konseling memberikan } \\
\text { layanan advokasi ketika siswa tidak } \\
\text { mendapatkan proses pembelajaran seperti } \\
\text { yang seharusnya. }\end{array}$
\end{tabular}

Analisa hasil angket dengan jumlah 45 siswa (sumber data) dengan jumlah pernyataan 30 diinterpretasikan dengan berpedoman rentang skala gradasi seperti yang ditetapkan di bab III, hasilnya sebagai berikut:

Hasil dari masing-masing item dijabarkan dalam tabel no.1 sampai dengan tabel no.30, sebagai berikut :

Berdasarkan hasil pengolahan data diketahui bahwa siswa yang menjawab ya $=73 \%$, dan kadang-kadang $=27 \%$, tidak pernah $=0 \%$. Dari data tersebut diinterpretasikan bahwa (siswa) aktif mengikuti pembelajaran sesuai dengan jadwal yang ada (item ini dikategorikan Baik)

Berdasarkan pedoman hasil wawancara dengan kepala sekolah, guru bimbingan dan konseling dan guru mata pelajaran maka hasilnya dapat diuraikan sebagai berikut :

1. Hasil Wawancara dengan kepala sekolah yaitu sebagai berikut :

a. Kepala sekolah sudah membina personil sekolah termasuk guru bimbingan dan konseling dalam menjalankan tugasnya. Untuk guru bimbingan dan konseling, kepala sekolah sering mengirim guru bimbingan dan konseling untuk mengikuti pelatihanpelatihan ataupun perkumpulan-perkumpulan guru bimbingan dan konseling.

b. Di sekolah dilaksanakan layanan secara klasikal untuk semua kelas baik itu kelas VII,VIII, dan IX. Dan layanan klasikal ini diberikan selama satu jam pelajaran dalam satu minggu. Dalam satu jam mata pelajaran itu berlangsung selama 45 menit.

c. Kepala sekolah selalu mengecek RPL yang dibuat oleh guru bimbingan dan konseling yang akan digunakan dalam pemberian layanan secara klasikal.

d. Di SMP YASPEN Tugu Ibu 2 Depok ini sudah memiliki ruang Bimbingan dan Konseling, namun ruangannya tidak begitu besar.

e. Setelah guru bimbingan dan konseling mengadakan layanan secara klasikal kepala sekolah juga mengevaluasinya dengan cara melihat hasil laporan dari pemberian layanan.

2. Hasil wawancara dengan guru bimbingan dan konseling yaitu sebagai berikut:

a. Guru bimbingan dan konseling membuat program yang didalamnya terdapat upaya dalam meningkatkan minat belajar siswa. Terdiri dari program tahunan, program semesteran, program bulanan dan mingguan.

b. Pelaksanaan program diberikan pada saat pelaksanaan layanan secara klasikal di kelas yaitu pada saat jam pelajaran bimbingan dan konseling

c. Proses pemberian layanan bimbingan dan konseling ini diberikan kepada siswa secara klasikal atau pun individual. Proses pemberian layanan secara klasikal diberikan kepada semua siswa. Untuk kelas VIII pemberial layanan bimbingan dan konseling secara klasikan diberikan pada hari senin. Kelas VIII-1 pada pukul 15.00-15.45 WIB, dan kelas VIII-2 pada pukul 13.00-13.45 WIB. 
d. Ketika ada siswa yang mengalami masalah tentang minat belajar, maka guru bimbingan dan konseling mencari tahu dulu apa yang menyebabkan masalah minat belajar, setelah tahu penyebabnya maka akan diberikan bantuan yang tepat untuk menyelesaikan masalah minat belajar yang dialami oleh siswa tersebut.

e. Dalam melakukan evaluasi untuk melihat hasil program yang dilaksanakan biasanya guru bimbingan dan konseling melakukan penilaiaan dengan menggunakan instrumen tertentu dan melakukan pengamatan pada siswa.

3. Hasil wawancara dengan guru mata pelajaran yaitu sebagai berikut :

a. Antusias siswa kelas VIII dalam mengikuti proses belajar dikelas mereka cukup bersemangat, hal ini ditandai dengan banyaknya siswa yang memperhatikan saat guru sedang menjelaskan materi pelajaran dan siswa tidak takut untuk bertanya ketika mereak tidak mengerti tentang materi yang sedang diajarkan. Selain itu kehadiran siswa pun cukup bagus.

b. Siswa memperhatikan ketika guru sedang menerangkan materi pelajaran. Siswa juga mencatat hal-hal yang di anggap penting.

c. Minat siswa pada saat mengikuti mata pelajaran dikelas sudah cukup baik. Karena siswa selalu berada didalam kelas pada saat pelajaran berlangsung.

d. Siswa mengerjakan tugas yang diberikan oleh guru dengan tepat waktu.

Tentu ada perbedaan antara siswa yang berminat untuk belajar dengan yang tidak berminat. Jika siswa berminat untuk belajar maka siswa akan selalau hadir dalam setiap mata pelajaran, semangat dalam mengikuti pelajaran, berpartisipasi ketika mata pelajaran sedang berlangsung misalnya mengajukan pertanyaan bila ada materi yang tidak dimengerti dan siswa yang berminat untuk belajar mereka mengerjakan tugas yang diberikan guru dengan tepat waktu

\section{Simpulan dan Saran}

Melihat permasalahan siswa yang begitu kompleks maka guru bimbingan dan konseling disarankan agar lebih mengoptimalkan dalam pemberian bantuan dan layanan kepada semua siswa terutama yang mengalami masalah, serta selalu bekerjasama dengan wali kelas, guru bidang studi dan warga sekolah lainnya, khususnya dalam meningkatkan minat belajar siswa agar siswa mendapatkan hasil yang optimal. Pelaksanaan program layanan bimbingan dan konseling yang telah dilaksanakan hendaknya lebih ditingkatkan lagi, mutu dan kualitasnya khususnya dalam meningkatkan dan memelihara minat belajar siswa, sehingga siswa mendapatkan hasil yang optimal dalam kegiatan pembelajaran.

\section{Daftar Pustaka}

Abidin, Z. (2006). Layanan bimbingan belajar sebagai upaya peningkatan kualitas proses belajar mengajar. Insania, 11(1), 34-48.

Arikunto, S. (2010). Prosedur Penelitian Suatu Pendekatan Praktek. Jakarta: Rieneka Cipta.

Dimyati, \& Mudjiono. (2009). Belajar Dan Pembelajaran. Jakarta: Rineka Cipta.

Hamalik, O. (2007). Dasar-dasar pengembangan kurikulum. Bandung: PT. Remaja Rosdakarya.

Kurniawan, L. (2015). Pengembangan Program Layanan Bimbingan dan Konseling

Komprehensif di SMA. Jurnal Psikologi Pendidikan \& Konseling, 1(1).

Permana, E. J. (2015). Pelaksanaan Layanan Bimbingan dan Konseling di Madrasah Aliyah

Negeri 2 Banjarnegara. PSIKOPEDAGOGIA Jurnal Bimbingan Dan Konseling, 4(2), 143-

151.

Prayitno. (2013). Jenis Layanan Dan Kegiatan Pendukung Konseling. Padang: UNP. 
Slameto. (2003). Belajar dan Faktor-faktor yang Mempengaruhinya. Jakarta: PT Rineka Cipta. Slameto. (2010). Belajar Dan Faktor-Faktor Yang Mempengaruhinya. Jakarta: Rineka Cipta.

Suryabrata, S. (2011). Psikologi Pendidikan. Jakarta: Rajawali Pers. 
https://ejournal.radenintan.ac.id/index.php/konseli http://dx.doi.org/10.24042/kons.v5i2.3058 